\title{
ДЕРЖАВНА МОВА ЯК ФАКТОР СДНАННЯ В УМОВАХ ЗБЕРЕЖЕННЯ МУЛЬТИЛІНГВАЛЬНОГО РОЗМАЇТТЯ СУЧАСНОЇ УКРАЇНИ
}

\author{
ГАЛИНА ШУМИЦЬКА \\ ДВНЗ „Ужгородський національний університет”, Ужгород - Україна \\ halyna.shumytska@uzhnu.edu.ua; ORCID: 0000-0001-7806-2963
JEZZYK PAŃSTWOWY JAKO CZYNNIK JEDNOCZĄCY RÓŻNORODNOŚCI WSPÓŁCZESNEJ UKRAINY \\ W WARUNKACH UTRZYMANIA MULTILINGWALNEJ
}

\author{
HAŁYNA SZUMYC'KA \\ Użhorodzki Uniwersytet Narodowy, Użhorod — Ukraina
}

STRESZCZENIE. Artykuł poświęcony jest oglądowi sytuacji językowej na Ukrainie, w szczególności na Zakarpaciu, w okresie jednego roku, tj. od wprowadzenia nowej ustawy o edukacji (wrzesień 2017) do przyjęcia projektu ustawy o funkcjonowaniu języka ukraińskiego jako państwowego (październik 2018). Stan języka ukraińskiego jako języka państwowego zbadano w kontekście wydarzeń społeczno-politycznych w kraju i na świecie. Na podstawie analiz, jak również przeprowadzonych w tym okresie wielu dogłębnych i sformalizowanych wywiadów z różnymi kategoriami respondentów możliwe jest zbadanie procesu wyboru języka, zwłaszcza języka edukacji, z uwzględnieniem rozwoju kulturalno-politycznego współczesnego społeczeństwa ukraińskiego w jego najbardziej wysuniętej na zachód części — Zakarpaciu.

Słowa kluczowe: sytuacja językowa, kwestia językowa, język urzędowy, język państwowy, język narodowy, strategie manipulacyjne, wspólnoty narodowe, wywiady dogłębne i sformalizowane 


\title{
STATE LANGUAGE AS A CONSOLIDATING FACTOR IN VIEW OF THE PRESERVATION OF THE MULTILINGUAL DIVERSITY IN MODERN UKRAINE
}

\author{
HALYNA SHUMYTSKA \\ Uzhhorod National University, Uzhhorod - Ukraine
}

\begin{abstract}
The article presents an overview of the lingual situation in Ukraine, in the Transcarpathian region in particular, within the time span of a year since the law On education (September 2017) was ratified till the adoption of the draft of the law whose aim is to ensure functioning of Ukrainian as the state language. The status of Ukrainian as a state language is considered in the closest connection with socio-political phenomena in the country and the whole world. The analysis of deep and formalized interviews with different categories of respondents conducted during this period sheds light on the process of language selection in the field of education, in particular as a sign of cultural and political development of contemporary Ukrainian society in its westernmost part - Transcarpathia.
\end{abstract}

Key words: lingual situation, lingual question, state language, manipulative strategies, national communities, deep and formalized interviews

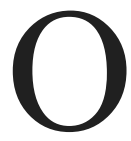

б’єкт нашого розгляду - мовна ситуація в Україні, що склалася протягом року (з вересня 2017 р. до жовтня 2018 р.), коли після ухвалення нового Закону Про освіmу на Закарпатті особливої гостроти набуло так зване “мовне питання”. Оскільки в Угорщині вибори відбулися навесні 2018 р., а Україна повинна їх провести в березні 2019 р., то, припускаємо, що зацікавлені, маніпулюючи мовною проблематикою, укотре відвертатимуть увагу громадськості від інших суспільно важливих питань. Дослідженню реалізації таких маніпулятивних стратегій у дискурсах сучасних українських політичних сил 3 різними поглядами стосовно питання "мовного будівництва" в державі присвячено монографію О. Рудої, у якій вона акцентує увагу на тому, що мовне питання в Україні є обов'язковим складником ідеологічної риторики різних політичних сил, порушується переважно в періоди перед виборами, виноситься на найвищий політичний рівень, формує специфічний дискурс - замкнену комунікативну ситуацію (подію), сформовану низкою лінгвальних і екстралінгвальних чинників. Разом $з$ політичною спекуляцією мовнореформаторськими ініціативами проглядається розпалювання міжнаціональної та міжконфесійної ворожнеч, виявляються тенденції до поглиблення ментальних суперечностей між громадянами зі сходу й заходу країни, що мають на меті відвернути увагу громадян від соціальних та економічних проблем, а також від браку інших життєво важливих заходів та ініціатив політиків і політич - 
них об’єднань [Руда 2018: 6]. I технології ці на теренах України, зокрема на Закарпатті, не нові. Напр., про подібний перебіг подій поч. ХХ ст. читаємо у спогадах і роздумах О. Сливки, коли „Підкарпаття, по-сьогоднішньому Закарпаття, а на мирному договорі в Парижі 10. IX. 1919 року як автономна частина під назвою «Подкарпатська Русь» було приєднано до Чехословацької республіки, яка утворилася на руїнах Австро-Угорщини, чехословацький уряд, в інтересі чехів і чехізації, від самого початку почав застосовувати на Підкарпатській Русі лозунг, вживаний вже в стародавньому Римі до народження Христа - «роз’єднуй і володарюй» (divide et impera). Роз'єднання, чвари, боротьба між народом розпочалися з перших років після приєднання до Чехословаччини на релігійному грунті між греко-католиками і православними, але в середині 20-х років вона вже обридла народу, стала затихати й цілком згасла. Тоді чехословацький уряд розпалив ще більше вогнище - «мовне питання» або «языковый вопрос»" [Як селяни... 2018].

Як зауважує сучасна українська дослідниця суспільного статусу староукраїнської (руської) та сучасної української мови I. Фаріон, „[...] проголошення суверенітету України кардинально вплинуло на зміну державної мовної політики. В іiі основі - новий для української мови державний статус, що, попри все, зазнає постійних політичних спроб із певних політичних середовищ (зокрема зовнішніх) обмежити його чи знівелювати. Потребаубезпечити та утвердити цю основну соціолінгвістичну категорію у житті незалежної держави зумовлює системне дослідження функціонування літературної мови в різні історичні епохи та у найтіснішому зв'язку із суспільно-політичними явищами" [Фаріон 2018б: 10]. 3 огляду на зазначене предметом цього дослідження $\epsilon$ відстеження тенденцій розв'язання мовного питання як визначального складника культурнополітичного розвитку сучасного українського суспільства в його найзахіднішій частині - Закарпатті.

Повертаючись до тези про порушення мовного питання як одного зі способів маніпулювання суспільною свідомістю в певні часові періоди, пригадаймо такий факт: у грудні 2012 р. на сесії Закарпатської обласної ради ухвалили рішення щодо надання угорській, румунській та русинській мовам статусу регіональних, легалізуючи так закон Ківалова-Колесніченка Про засади мовної державної політики на території області. Це рішення не мало жодних ані юридичних, ані практичних наслідків, оскільки в бюджеті не були передбачені на це кошти. Зміст цього закону прокоментував керівник Закарпатського інституту політичних досліджень В. Пащенко: „Бо скоро будуть вибори, у тому числі у Виноградівському районі, де проживають угорці. Тому їм не треба відштовхувати угорськомовний електорат. [...] Яка за цим мета, не знаю. $Є$ дві гіпотези. Або елементарна глупість - робити, щоби щось робити. Або ж це може бути більш тонка гра, яка має на меті взагалі Україну розколоти. Бо ці питання фактично Україну розколюють. За мовною 
ознакою, перш за все. [...] Щодо румунської та русинської мов — це взагалі беззмістовна розмова. Бо навіть згідно з цим недолугим законом на території має проживати 10 \% представників тої чи іншої нацменшини. Румунів же в області - $3 \%$, не більше. Русини — це взагалі не ідентифікована нація, а літературної русинської мови в принципі немає" [Дубовик 2018].

"Мовне нагнітання" знову триває на Закарпатті ось уже рік, і почалося воно після ухвалення нового Закону Про освіту у вересні 2017 р., хоч могло бути зумовлене й суто господарською метою. Таку думку висловлює український політолог В. Цибулько, зокрема він зауважує: „Звісно, на Закарпатті є свої шовіністичні закладки, але вони більше технологічні, ніж світоглядні. Хтось (Російська Федерація - ред.) вливає кошти, щоб створити там певні лінії напруження. Хоч це, скоріш за все, пов'язано із господарською діяльністю - розподілом активів. Хочу нагадати, що всі ті сепаратистські думки, які звучали минулого року, коли придумали експеримент з перенаправленням половини митних зборів на інфраструктуру регіонів, були своєрідним тиском на Київ. Тоді ж кошти розподілили між Одеською, Чернівецькою, Львівською та Волинською областями. На Закарпатті хотіли покращити інфраструктуру доріг, адже їхня якість там не найкраща. Але тоді їм тої можливості не дали і почалося" [Мовне питання на... 2018].

Відразу у вересні 2017 р. під час восьмої сесії депутати Закарпатської облради схвалили звернення до Президента України з проханням ветувати новий закон Про освіту, що обмежує права нацменшин, які проживають в області, а голова ОДА Г. Москаль назвав законопроєкт таким, що не відповідає європейським нормам [Закарпатські депутати... 2018].

Порівнюючи підхід до вирішення мовного питання на Закарпатті й у Сингапурі, В. Чепинога зауважує, що „підтримка Закарпатською обласною радою угорської мови (фактично всупереч державній) - значно загрозливіша, ніж може видатися на перший погляд. Адже мова йде не про сьогоднішній комфорт мешканців, а про тривалі стратегічні інтереси та пріоритети держави. Державна мова - це елементарна частина ДНК нації, що не повинна видозмінюватися залежно від примх окремих етноспільнот" [Чепинога 2018].

Тим часом у жовтні 2017 р. угорці Закарпаття виступили з провокаційним зверненням щодо мовного питання. Зокрема, як пише громадський правозахисник В. Грегор, захід був організований у Закарпатському угорському інституті ім. Ф. Ракоці ІІ з подання депутата облради та керівника цієї фінансової інституції I. Ороса, за підтримки першого заступника голови Закарпатської облради Й. Борто. За його словами, захід був прихований від громадськості й проводився під прикриттям позачергової загальної конференції угорськомовного педагогічного товариства. Хоча самі педагоги, опитані перед початком конференції, повідомили, що тут повинна відбутися щорічна чергова конференція освітян, під час якої традиційно звітують і виступають представ- 
ники угорського суспільства. Також він повідомив, що спробував відвідати цей захід, проте на вході його не пропустили працівники установи разом 3 приватною охороною. Тим часом схвалене на цій конференції звернення було опубліковане на угорськомовному сайті „Kárpátalja.ma” [див.: Угорці Закарпаття... 2018].

Водночас окремі націоналістичні організації Закарпаття звернулися до депутатів облради не приймати цього звернення, порівн.: „У випадку схвалення подібного роду звернення депутатський корпус Закарпатської обласної ради фактично виступить проти утвердження та розвитку української мови та стане на шлях антиукраїнської діяльності щодо української мови як державної мови в Україні. Такі антиукраїнські дії з боку різного роду сепаратистських сил в останні дні були спровоковані не без участі московсько-путінського режиму та промосковського уряду Угорщини Віктора Орбана в особі їхніх кишенькових політичних організацій на Закарпатті, зокрема «КМКС - партія угорців України»” [Мовне питання в... 2018]. Це звернення підписали представники національно-патріотичного об'єднання „Україна Соборна”, президія Закарпатського обласного товариства борців за незалежність України у XX ст., Рада Християнсько-народної спілки Закарпаття, Рада Закарпатської ГО „Молодь Закарпаття”, Закарпатський осередок ГО „Айдар - волонтерська допомога”, Ужгородська реферантура ГО „Новий Вогонь”.

У цьому ж матеріалі наведена розлога цитата з виступу голови Закарпатської ОДА Г. Москаля, який, як видається, наводить абсолютно резонні коментарі щодо провадження мовної політики в Україні у принципі, порівн.: „Коли я чую, як деякі нардепи кричать, що на Закарпатті суцільна зрада, бо національні меншини не спілкуються державною мовою, то мені хочеться спитати - чому ви не почнете вирішувати мовні проблеми з себе? Адже в Україні досі діє закон «Колесніченка-Ківалова», прийнятий улітку 2012 року. Саме цей закон став одним із чинників, що призвели до Революції Гідності, а Росія використала його для окупації Криму та розв'язання війни на Донбасі. Закон «Колесніченка-Ківалова» бере під захист у тому числі русинську мову, однак про це у Верховній Раді чомусь ніхто не говорить! То краще скасуйте чи внесіть зміни в цей закон, а не використовуйте багатонаціональне Закарпаття як полігон для піару й некомпетентних заяв!” [Мовне питання в... 2018].

Наведені думки обгрунтовані бодай тому, що Закон України Про засади державної мовної політики від 3 липня 2012 р. ("Колесніченка-Ківалова"Г. Ш.) визнано неконституційним тільки 28 лютого 2018 р. [Рішення Конституційного... 2018], новий проєкт правопису, запропонований комісією 3 питань правопису при МОН для обговорення 15 серпня 2018 р. [MOН пропонує... 2018], співголовами якої є доктор фізико-математичних наук М. Стріха i доктор економічних наук С. Пирожков, мовознавці жорстко критикують, порівн.: „[...] щоб загасити (передусім Німчукове) невідступне прагнення 
питомих правописних змін, треба було організувати процес очолення цих змін людям з іншим, радянським, і промосковським світоглядом. Ото й вийшло: ні тепле ні холодне, і вашим і нашим" [Фаріон 2018а]. Щодо перспектив нового мовного закону, ухваленого Верховною Радою України в першому читанні 4 жовтня 2018 р., то віднаходимо твердження сучасних політичних експертів про те, що „Україна остаточно зробила як власний цивілізаційно-інтеграційний вибір, так і серйозно зайнялася питанням своєї ідентичності; поряд зі збройною відсіччю окупанту активізувала боротьбу за державність та своїх громадян і на культурному фронті” [Петровець 2018], спираючись при цьому аж на чотири зареєстровані у парламенті законодавчі ініціативи (законопроекти № 5556, № 5669, № 5670 та № 5670-д), покликані врегулювати мовне питання.

Міністр закордонних справ України П. Клімкін після відвідин Закарпаття в грудні 2017 р. прокоментував позицію України щодо мовного питання в цьому регіоні: „Мовне питання на Закарпатті штучно політизоване. Воно має бути вирішене в діалозі з громадою” [Мовне питання на ... 2018].

Саме така мета - налагодження діалогу з громадою - визначила більш ніж піврічну роботу викладачів Ужгородського національного університету в рамках проєкту „Через діалог із нацменшинами - до врегулювання мовної ситуації в Закарпатті” (реалізується за фінансової підтримки СС та Міжнародного фонду „Відродження” впродовж травня-грудня 2018 р.), що передбачає проведення низки глибинних та формалізованих інтерв'ю зі школярами, іхніми батьками, студентами, учителями, керівниками навчальних закладів, громадськими діячами, представниками політичних партій, роботодавцями, а також улаштування публічних тематичних круглих столів. Проміжкові його результати досить передбачувані, однак проєкт дав можливість більше комунікувати його виконавцям 3 представниками національних громад Закарпатської області, і це теж сприяє пожвавленню діалогу й припиненню суперечностей щодо вибору мови викладання. Крім того, виконання проєкту дало можливість переконатися в готовності представників національних громад вести конструктивний діалог щодо врегулювання питання мови навчання в освітніх закладах, пошуку оптимальних шляхів імплементації статті 7 Закону України Про освіту. Майже в усіх респондентів $\epsilon$ усвідомлення, що громадянин України має знати державну мову, однак більшість акцентує на тому, що без економічного підгрунтя сама мова не $є$ стимулом до їі вивчення, а також наголошують на проблемах, пов'язаних 3 методикою викладання української мови в загальноосвітніх закладах [див.: Шумицька 2018].

Проведені круглі столи допомогли здійснити такі дії: 1) промоніторити ситуацію щодо викладання української мови й літератури в школах 3 викладанням мовами національних меншин; 2) почути від самих педагогів про труднощі, що виникають у навчальному процесі в полілінгвальному се- 
редовищі; 3) донести до вчителів інформацію про проєкт і його мету (щоб підготувати виконавцям проєкту підгрунтя на місцях для наступного проведення формалізованих і глибинних інтерв'ю) [див.: Толочко 2018б]; 4) проаналізувати досвід європейських країн у врегулюванні мовного питання, спроєктувати його на українські реалії, подивитися на них через призму поглядів істориків, політологів, юристів, філологів, фахівців із соціальних комунікацій, щоб виробити пропозиції, оптимальні для України загалом i Закарпаття зокрема [див.: Толочко 2018а].

Напруга в стосунках з Будапештом тим часом не спадає. Незважаючи на те, що фактично з лютого 2018 р., тобто від часу, коли Конституційний Суд України визнав “закон КК” - Ківалова-Колесніченка (подекуди його називали “закон ККК” - Кремля-Ківалова-Колесніченка Про основи державної мовної політики - неконституційним), і аж до жовтня цього року, коли Верховна Рада України ухвалила проєкт закону про державну мову в першому читанні, країна жила в правовому вакуумі: мовне питання нічим не регулювалося. Саме цей важливий внутрішньополітичний український крок міністр закордонних справ Угорщини П. Сіярто назвав на національному громадському телебаченні М1 частиною антиугорської кампанії в Україні: „Мовний закон України робить неможливим використання угорської мови та мови решти національних меншин у сфері державного управління, 3MI і культурі. Цей та інші кроки ідуть урозріз із основоположними правами й нормами міжнародного права. Україна постійно порушує його та свої міжнародні обов'язки. Тому ми й надалі будемо виступати проти прискорення євроінтеграційної співпраці України на всіх міжнародних форумах і в кожному окремому випадку станемо на захист членів угорської етнічної громади на Закарпатті" [Закон про мову... 2018]. Зауважмо також, що вже наступного дня колишній міністр фінансів Угорщини, голова руху „За сучасну Угорщину” Л. Бокрош підтримав Україну й засудив поведінку угорського МЗС: „Угорська дипломатія завдає неймовірної шкоди закарпатській угорській громаді, кількість якої швидко зменшується. Замість того, щоб намагатись домовитись із українською владою, вона розпалює вогонь ненависті. Навіть не питання, що головну роль тих, хто програв, отримають закарпатські угорці” [Колишній угорський... 2018].

Отже, ситуацію, що склалася на Закарпатті, можна інтерпретувати, з одного боку, як політичну гру, яка, однак, будь-якої миті може вийти з-під контролю того, хто іï ініціює, i, з другого боку, як добре продуману довготривалу геополітичну стратегію, спрямовану на розподіл української території.

Глава МЗС України П. Клімкін, який відвідав регіон, убачає в небажанні Угорщини вирішити питання щодо українського закону про освіту й розблокувати зустрічі української делегації на вищому рівні в НАТО спроби Росії використати ситуацію на Закарпатті, що може загрожувати й Україні, і Угорщині, і Європі [Клімкін: спроби... 2018]. 
Тож питання врегулювання мовної ситуації в регіонах компактного проживання етноспільнот, передусім на Закарпатті, потребує пильної уваги як української влади, так і європейського співтовариства. Пошук компромісних рішень на користь кожної зі сторін і далі на часі.

\section{Список використаної літератури}

Дубовик О., „Мовне питання на Закарпатті піднімають або через глупство, або ж для розколу країни", [в:] Електронний ресурс: https://gazeta.ua/articles/politics/_movnepitannya-na-zakarpatti-pidnimayut-abo-cherez-glupstvo-abo-zh-dlya-rozkolukrayini/474383?mobile=true $(22.10 .2018)$.

Закарпатські депутати просять Порошенка ветувати Закон „,Про освіту”, [в:] Електронний ресурс: https://zik.ua/news/2017/09/21/zakarpatski_deputaty_prosyat_poroshenka_ vetuvaty_zakon_pro_osvitu_1171779 (22.10.2018).

Закон про мову робить неможливим використання угорської мови у публічномупросто$p i-$ - Сійлрто, [в:] Електронний ресурс: https://www.radiosvoboda.org/a/news-szijartoukraine-hungary/29538140.html (22.10.2018).

Клімкін: спроби РФ використати ситуаиію на Закарпатті загрожують Європі, [в:] Електронний ресурс: https://www.eurointegration.com.ua/news/2018/10/12/7088109/ (22.10.2018).

Колишній угорський міністр став на захист України у конфлікті з Будапештом, [в:] Електронний ресурс: https://www.eurointegration.com.ua/news/2018/10/12/7088111/ (22.10.2018).

Мовне питання в Закарпатті: Націоналісти проти обласної влади, обласна влада проти нардеniв, [в:] Електронний pecypc: http://prozak.info/index.php/Suspil-stvo/Movne-pitannya- vZakarpatti-Nacionalisti-proti-oblasnoyi-vladi-oblasna-vlada-proti-nardepiv (22.10.2018).

Мовне питання на Закарпатті підняли через господарську діяльність, - Цибулько, [в:] Електронний ресурс: https://zik.ua/news/2017/09/22/movne_pytannya_na_zakarpatti_ pidnyaly_cherez_gospodarsku_diyalnist_tsybulko_1172675 (22.10.2018).

„Мовне питання на Закарпатті штучно політизоване”, - міністр закордонних справ України, [в:] Електронний ресурс: https://goloskarpat.info/power/5a2178ef8d491/?utm_ content $=031$ (22.10.2018).

МОН пропонує для громадського обговорення проект нової редакиії українського правопису, [в:] Електронний pecypc: https://mon.gov.ua/ua/news/mon-proponuye-dlya-gromadskogoobgovorennya-proekt-novoyi-redakciyi-ukrayinskogo-pravopisu (22.10.2018).

Петровець О., „Закон Ківалова-Колесніченка” скасовано. Що далі?, [в:] Електронний pecypc: https://www.pravda.com.ua/columns/2018/03/7/7173902/ (22.10.2018).

Рішення Конституиійного Суду України у справі за конституиійним поданням 57 народних депутатів України щодо відповідності Конституції Украӥни (конституційності) Закону України „Про засади державної мовної політики”, [в:] Електронний ресурс: http://www.ccu.gov.ua/sites/default/files/docs/2-p_2018.pdf (22.10.2018). 
Руда О. Г., Мовне питання як об 'єкт маніпулятивних стратегій у сучасному українському політичному дискурсі, НАН України, Ін-т укр. мови, Київ 2012.

Толочко Н., Науковці УжНУ шукають для Украӥни ї̈ унікальний шлях вирішення мовного питання, [в:] Електронний ресурс: http://mediacenter.uzhnu.edu.ua/news/naukovtsiuzhnu-z-yasovuvaly-mehanizmy-realizatsiyi-movnoyi-polityky-v-polilingvalnomususpilstvi/2018-06-17-23030 (22.10.2018a).

Толочко Н., Через діалог до консенсусу: в УжНУ відбувся круглий стіл, присвячений мовній ситуації в Закарпатті, [в:] Електронний ресурс: http://mediacenter.uzhnu.edu.ua/news/ cherez-dialog-do-konsensusu-v-uzhnu-vidbuvsya-kruglyj-stil-prysvyachenyj-movnijsytuatsiyi-v-zakarpatskij-oblasti/2018-06-03-22498 (22.10.20186).

Угориі Закарпаття виступили з провокаційним зверненням щодо “мовного питання”, [в:] Електронний ресурс: https://antikor.com.ua/articles/196040-ugortsi_zakarpattja vistupili_z_provokatsijnim_zvernennjam_shchodo_movnogo_pitannja (22.10.2018).

Фаріон І., Проєкт правопису 2018 - дитя компромісу: і вашим, і нашим, [в:] Електронний pecypc: https://blogs.pravda.com.ua/authors/farion/5b8c59e9296a4/ (22.10.2018a).

Фаріон I., Суспільний статус староукраӥнської (руської) мови у XIV-XVII століттях: мовна свідомість, мовна дійсність, мовна перспектива, Львів 20186.

Чепинога В., Мовне питання на Закарпатmі й у Сінгапурі, [в:] Електронний ресурс: http:// www.umoloda.kiev.ua/number/0/2010/116057/ (22.10.2018б).

Шумицька Г., Ужсгород - Чернівці - Одеса: мова освіти як інструмент інтеграції суспільства, [в:] Електронний ресурс: http://mediacenter.uzhnu.edu.ua/news/uzhgorodchernivtsi-odesa-mova-osvity-yak-instrument-integratsiyi-v-suspilstvo/2018-10-21-26511 (22.10.2018).

Як селяни на Закарпатті “языковый вопрось” вирішували, [в:] Електронний ресурс: https://gazeta.ua/articles/istoriya-movi/_ak-selyani-na-zakarpatti-yazykovyj-voprosvirishuvali/689827? $\mathrm{mobile}=$ true $(22.10 .2018)$.

\section{Spysok vykorystanoi literatury [References]}

Dubovyk O., „Movne pytannia na Zakarpatti pidnimaiut abo cherez hlupstvo, abo zh dlia rozkolu krainy" [,, The Language Issue in Transcarpathia is Raised Either Because of the Incompetence or for the Reason of Splitting the Country'], [v:] Elektronnyi resurs: https:/gazeta.ua/articles/politics/_movne-pitannya-na-zakarpatti-pidnimayut-abo-cherezglupstvo-abo-zh-dlya-rozkolu-krayini/474383?mobile=true (22.10.2018).

Zakarpatski deputaty prosiat Poroshenka vetuvaty Zakon „Pro osvitu” [Transcarpathian Deputies Ask Poroshenko to Put a Veto on the Law ,On Education”], [v:] Elektronnyi resurs: https://zik.ua/news/2017/09/21/zakarpatski_deputaty_prosyat_poroshenka_vetuva ty_zakon_pro_osvitu_1171779 (22.10.2018).

Zakon pro movu robyt nemozhlyvym vykorystannia uhorskoi movy u publichnomu prostori Siiiarto [The Language Law Makes it Impossible to Use the Hungarian Language in Public 
Space - Siyarto], [v:] Elektronnyi resurs: https://www.radiosvoboda.org/a/news-szijartoukraine-hungary/29538140.html (22.10.2018).

Klimkin: sproby RF vykorystaty sytuatsiiu na Zakarpatti zahrozhuiut Yevropi [Klimkin: Russia's Attempts to Use the Situation in Transcarpathia are Threatening Europe], [v:] Elektronnyi resurs: https://www.eurointegration.com.ua/news/2018/10/12/7088109/ (22.10.2018).

Kolyshnii uhorskyi ministr stav na zakhyst Ukrainy u konflikti z Budapeshtom [Former Hungarian Minister Stood for Ukraine in Conflict with Budapest], [v:] Elektronnyi resurs: https://www.eurointegration.com.ua/news/2018/10/12/7088111/ (22.10.2018).

Movne pytannia $v$ Zakarpatti: Natsionalisty proty oblasnoi vlady, oblasna vlada proty nardepiv [The Language Issue in Transcarpathia: Nationalists Against the Regional Authorities, the Regional Power Against Deputies], [v:] Elektronnyi resurs: http://prozak.info/index.php/ Suspil-stvo/Movne-pitannya-v-Zakarpatti-Nacionalisti-proti-oblasnoyi-vladi-oblasnavlada-proti-nardepiv (22.10.2018).

Movne pytannia na Zakarpatti pidnialy cherez hospodarsku diialnist, - Tsybulko[The Language Issue in Transcarpathia was Raised through Economic Activity, - Tsybulko], [v:] Elektronnyi resurs: https://zik.ua/news/2017/09/22/movne pytannya na zakarpatti pidnyaly_cherez_gospodarsku_diyalnist_tsybulko_1172675 (22.10.2018).

„Movne pytannia na Zakarpatti shtuchno polityzovane”, - ministr zakordonnykh sprav Ukrainy [,, The Language Issue in Transcarpathia is Artificially Politicized" - Minister of Foreign Affairs of Ukraine], [v:] Elektronnyi resurs: https://goloskarpat.info/ power/5a2178ef8d491/?utm_content=031 (22.10.2018).

MON proponuie dlia hromadskoho obhovorennia proekt novoi redaktsii ukrainskoho pravopysu [MES Proposes a New Draft for Public Discussion Concerning Ukrainian Spelling], [v:] Elektronnyi resurs: https://mon.gov.ua/ua/news/mon-proponuye-dlya-gromadskogoobgovorennya-proekt-novoyi-redakciyi-ukrayinskogo-pravopisu (22.10.2018).

Petrovets O., „Zakon Kivalova-Kolesnichenka” skasovano. Shcho dali? [,, The Law of KivalovKolesnichenko" has been Canceled. What's Next?], [v:] Elektronnyi resurs: https://www. pravda.com.ua/columns/2018/03/7/7173902/ (22.10.2018).

Rishennia Konstytutsiinoho Sudu Ukrainy u spravi za konstytutsiinym podanniam 57 narodnykh deputativ Ukrainy shchodo vidpovidnosti Konstytutsii Ukrainy (konstytutsiinosti) Zakonu Ukrainy „Pro zasady derzhavnoi movnoi polityky” [The Decision of the Constitutional Court of Ukraine in the Case of the Constitutional Petition of 57 People's Deputies of Ukraine on the Compliance with the Constitution of Ukraine (Constitutionality) of the Law of Ukraine „On the Principles of State Language Policy”], [v:] Elektronnyi resurs: http://www.ccu.gov. ua/sites/default/files/docs/2-p_2018.pdf (22.10.2018).

Ruda O. H., Movne pytannia yak obiekt manipuliatyvnykh stratehii u suchasnomu ukrainskomu politychnomu dyskursi [The Language Question as an Object of Manipulative Strategies in the Contemporary Ukrainian Political Discourse], NAN Ukrainy, In-t ukr. movy, Kyiv 2012.

Tolochko N., Naukovtsi UzhNU shukaiut dlia Ukrainy yii unikalnyi shliakh vyrishennia movnoho pytannia [Scientists of UzhNU are Looking for Ukraine's Unique Solution of the Language Question], [v:] Elektronnyi resurs: http://mediacenter.uzhnu.edu.ua/ news/naukovtsiuzhnu-z-yasovuvaly-mehanizmy-realizatsiyi-movnoyi-polityky-v-po-lilingvalnomususpilstvi/2018-06-17-23030 (22.10.2018a). 
Tolochko N., Cherez dialoh do konsensusu: v UzhNU vidbuvsia kruhlyi stil, prysviachenyi movnii sytuatsii v Zakarpatti [Through Dialogue to Consensus: Round Table was Held in UzhNU, Dedicated to the Linguistic Situation in Transcarpathia], [v:] Elektronnyi resurs: http://mediacenter.uzhnu.edu.ua/news/cherez-dialog-do-konsensusu-v-uzhnu-vidbuvsyakruglyj-stil-prysvyachenyj-movnij-sytuatsiyi-v-zakarpatskij-oblasti/2018-06-03-22498 (22.10.2018b).

Uhortsi Zakarpattia vystupyly z provokatsiinym zvernenniam shchodo "movnoho pytannia" [Hungarians of Transcarpathia Made Aprovocative Appeal Concerning "Language Question"], [v:] Elektronnyi resurs: https://antikor.com.ua/articles/196040ugortsi_zakarpattja_vistupili_z_provokatsijnim_zvernennjam_shchodo_movnogo_pitannj a (22.10.2018).

Farion I., Proiekt pravopysu 2018 - dytia kompromisu: $i$ vashym, i nashym [Spelling Project 2018 - a Child of a Compromise: Both Yours and Ours], [v:] Elektronnyi resurs: https:// blogs.pravda.com.ua/authors/farion/5b8c59e9296a4/ (22.10.2018a).

Farion I., Suspilnyi status staroukrainskoi (ruskoi) movy u XIV-XVII stolittiakh: movna svidomist, movna diisnist, movnaperspektyva [Social Status of the OldUkrainian(Ruthenian) Language in XIV-XVII Centuries: Linguistic Consciousness, Linguistic Reality, Linguistic Perspective], Lviv 2018b.

Chepynoha V., Movne pytannia na Zakarpatti y u Sinhapuri [Language Question in Transcarpathia and Singapore], [v:] Elektronnyi resurs: http://www.umoloda.kiev.ua/ number/0/2010/116057/ (22.10.2018).

Shumytska H., Uzhhorod - Chernivtsi - Odesa: mova osvity yak instrument intehratsii suspilstva [Uzhhorod - Chernivtsi - Odessa: Language of Education as a Tool of Society Integration], [v:] Elektronnyi resurs: http://mediacenter.uzhnu.edu.ua/news/uzhgorodchernivtsi-odesa-mova-osvity-yak-instrument-integratsiyi-v-suspilstvo/2018-10-21-26511 (22.10.2018).

Yak seliany na Zakarpatti "yazykovoy vopros" vyrishuvaly [How did Peasants of Transcarpathia Solved the "Linguistic Question"], [v:] Elektronnyi resurs: https:/gazeta.ua/articles/istoriya- movi/_ak-selyani-na-zakarpatti-yazykovyj-voprosvirishuvali/689827? mobile=true (22.10.2018). 